\title{
Komunikasi Dwisistem pada Anak dengan Ibu Tunarungu: Sebuah Studi Kasus
}

\section{Dual System Communication In Children With Deaf Mothers: A Case Study}

\author{
Irmayani Putri, Reniwati, Bahren \\ bahren@hum.unand.ac.id \\ Fakultas Ilmu Budaya Universitas Andalas
}

\begin{abstract}
This article describes the form and meaning of the sign language used by a child with a deaf mother. Data provided by referral method which are using tapping techniques. Data analyzed uses a pragmatic method with speech partners and determination of other languages.

The results show that the object communicates with his mothers occurs hand gestures and body gestures. In this case, the sign language used is not the standard sign language but a habit that is formed because of the similarity with the subject.
\end{abstract}

Keywords: dual system communication, deaf, sign language

\section{PENGANTAR}

Objek penelitian dalam makalah ini adalah seorang anak dengan ibu tuna rungu. Seorang anak yang normal yang terlahir dari ibu yang merupakan seorang tunarungu bernama Rafi yang lahir pada tahun 2013. Ibunya mengidap tuna rungu semenjak kecil. Ayah Rafi normal dan tidak memiliki gangguan bicara.

Rafi terlahir normal tanpa gangguan bicara maupun pendengaran. Dia memperoleh kemampuan bahasa verbal dari anggota keluarga selain ibunya. Sistem keluarga komunal Minangkabau tentunya memiliki andil besar dalam pemerolehan bahasa Rafi. Kondisi ibu Rafi yang tuna rungu tidak mampu mengajarkannya Rafi untuk berbicara secara verbal, Rafi kemudian diajarkan oleh orang terdekat lain di lingkungannya, seperti ayah, nenek, etek (bibi), pak etek (paman).

Pemerolehan bahasa anak dari lingkungannya tersebut sejalan dengan pendapat Tarigan (Tarigan, 1988), walaupun sering tidak disadari, perkembangan bahasa sang anak juga turut dipengaruhi oleh insan yang menjaga atau pengasuhnya sehari-hari. Pengasuh yang dimaksudkan di sini mungkin saja ibu, ayah, nenek, bibi, atau pembantu.

Bahasa ibu yang diperoleh Rafi adalah bahasa Minangkabau yang digunakan di Halaban, tempat lingkungan Rafi dibesarkan. Selain bahasa Minangkabau verbal, Rafi juga mampu berkomunikasi dengan ibunya yang tunarungu 


\section{Jurnal Elektronik WACANA ETNIK - Vol 7 No 1 April 2018, (1 - 10) \\ p ISSN 2089-8746, e ISSN 2302-7142}

menggunakan bahasa isyarat/bahasa sinyal. Rafi paham bagaimana ia harus berkomunikasi dengan orang selain ibunya dengan bahasa verbal.

Suatu saat, Rafi mencolek ibunya kemudian meliuk-liukkan tangan sembari menunjuk ke arah kolam ikan. Tidak hanya komunikasi satu arah, Rafi juga paham apa yang dimaksud oleh ibunya dalam bahasa isyarat. Di lain waktu, ibu Rafi mencolek dan mengibaskan tangan ke arah rumahnya, tak lama Rafi mengatakan "Pulang $l u, B u$. Dapat dilihat Rafi paham dan mengerti bagaimana ia harus berkomunikasi dengan ibunya menggunakan bahasa isyarat dan ia sangat paham apa yang dimaksud oleh ibunya dengan menggunakan bahasa isyarat.

Menurut Chaer (Chaer, 2003b), kanak-kanak yang lahir dengan alat artikulasi dan auditori yang normal akan dapat mendengar kata-kata dengan telinganya dengan baik dan juga akan dapat menirukan kata-kata itu. Pada mulanya ucapan tiruan itu hanya mirip, tapi lambat laun akan menjadi tegas dan jelas. Proses memproduksi kata-kata itu berlangsung terus sejalan dengan proses pengembangan pengenalan dan pengertian.

Jika dilihat dari penggunaan bahasa verbal, Rafi tidak memiliki gangguan berbicara, seperti tunawicara, gagap, latah, cadel. Rafi sudah mampu menirukan apa yang diucapkan oleh orang sekelilingnya. Rafi mampu berkomunikasi dengan dua cara yaitu verbal dan nonverbal (isyarat). Seorang anak mampu berkomunikasi dengan lingkungannya yang menggunakan bahasa verbal dan bagaimana ia berkomunikasi dengan seorang ibu yang tunarungu.

\section{METODE DAN KERANGKA TEORI}

Teknik dasar yang digunakan untuk memperoleh data ialah teknik sadap Teknik sadap merupakan pelaksanaan metode simak dengan menyadap penggunaan bahasa seseorang atau beberapa orang. Penggunaan bahasa yang disadap dapat berbentuk lisan dan tulisan. Teknik lanjutan yang digunakan adalah Teknik Simak Libat Cakap, menyimak semua yang disampaikan oleh narasumber dan ikut terlibat dalam percakapan tersebut; Teknik Rekam dan Catat, merekam menggunakan alat rekam audio visual dan mencatat untuk memperkuat perolehan data.

Metode analisis yang digunakan adalah padan pragmatis dengan alat penentunya mitra wicara. Metode ini digunakan karena pada dasarnya bahasa memiliki hubungan dengan yang berada di luar bahasa. Jika seorang anak berkomunikasi dengan ibunya yang tunarungu dengan mencolek bahu ibunya, maka isyarat itu menimbulkan reaksi dari seorang ibu, yaitu dengan melihat kepada anaknya.

Metode analisis selanjutnya ialah metode padan translasional. Metode ini merupakan metode padan yang alat penentunya bahasa lain. Dalam komunikasi verbal, Rafi menggunakan bahasa Minangkabau sehingga perlu diterjemahkan ke dalam bahasa Indonesia.

Secara teoretis, kajian makalah ini adalah kajian psikolinguistik. Menurut Dardjowidjojo (Dardjowidjojo, 2012), psikolinguistik merupakan ilmu yang mempelajari proses-proses mental yang dilalui oleh manusia dalam mereka berbahasa. Dalam praktiknya Chaer (Chaer, 2003b) menyatakan psikolinguistik mencoba menerapkan pengetahuan linguistik dan psikologi pada masalah-masalah seperti pengajaran dan pembelajaran bahasa, pengajaran membaca permulaan dan membaca lanjut, kedwibahasaan dan kemultibahasaan, penyakit bertutur seperti afasia, 
gagap, dan sebagainya; serta masalah masalah sosial lain yang menyangkut bahasa, seperti bahasa dan pendidikan, bahasa dan pembangunan nusa dan bangsa.

Pemerolehan bahasa merupakan bagian dari psikolinguistik. Pemerolehan bahasa atau akuisisi bahasa merupakan proses yang berlangsung dalam otak seseorang kanak-kanak ketika ia memperoleh bahasa pertama dari ibunya. Bahasa ibu merupakan bahasa pertama yang dikuasai oleh anak (Chaer, 2003a; Dardjowidjojo, 2012).

Masa kritis pemerolehan bahasa adalah periode kehidupan manusia yang ditentukan secara biologis sebagai masa pemerolehan bahasa secara lebih mudah. Dan di luar masa ini, pada umumnya pembelajar harus mengalami kesulitan dalam pemerolehannya, hipotesis masa kritis mengklaim bahwa ada masa paling efektif dalam pemerolehan bahasa, dan masa tersebut terjadwal secara biologis dan alamiah (Arifuddin, 2013). Sebelum mampu berbahasa secara sempurna, anak melalui beberapa tahapan. Bisa dikatakan bahasa kanak-kanak itu berkembang setahap demi setahap, mulai dari bunyi, kata, frasa, dan kalimat (Chaer, 2003b).

Bahasa tanda dapat dilakukan dengan berbagai cara gerak-gerik anggota badan, perubahan mimik, tepuk tangan dan sejenisnya dapat dipakai sebagai sarana bahasa tanda. Bahasa tanda bisa digunakan sebagai penunjang komunikasi verbal, misalnya dengan memanggil orang yang jauh dalam kebisingan. Jika dipanggil dengan menggunakan bahasa verbal, maka tidak akan terjangkau oleh suara. Menggunakan bahasa tanda dengan melambaikan tangan merupakan cara yang efektif.

Kelompok tertentu menekankan komunikasi melalui bicara dan membaca ujaran, metode ini dinamai dengan metode oral. Kelompok lain menekankan kepada penggunaan isyarat, dinamakan metode manual. Dalam berkomunikasi secara manual, anak tunarungu umumnya menggunakan dua cara bersama-sama, yaitu dengan menyatakan beberapa kata melalui bahasa isyarat dan ejaan jari (Moores, 2001).

Menurut Djajasudarma (Djajasudarma, 1993), tanda nonverbal digunakan manusia untuk berkomunikasi, sama halnya dengan tanda verbal. Tanda nonverbal dapat dibedakan menjadi dua, yaitu tanda yang dihasilkan anggota badan (Body gesture) dan tanda yang dihasilkan oleh bunyi (suara). Tanda yang dihasilkan anggota badan (Body gesture) dikenal sebagai bahasa isyarat, misalnya: (1) Acungan jempol yang bermakna hebat, bagus; (2) Mengangguk yang bermakna ya, menghormati; (3) Menggelengkan kepala bermakna tidak atau bukan; (4) Membelalakkan mata bermakna heran, marah; (5) Mengacungkan telunjuk yang bermakna tidak mengerti, setuju; (6) Menunjuk bermakna itu, satu orang.

Bahasa tanda bisa menjadi sebuah keharusan untuk berkomunikasi bagi sebagian orang. Hal tersebut terjadi pada orang tuna rungu atau tuna wicara. Adanya gangguan otak ataupun alat ucap yang dialami oleh seorang tuna rungu menyebabkan bahasa isyaratlah yang menjadi jalan keluar mereka untuk berkomunikasi dengan lingkungannya.

Bahasa tanda atau bahasa sinyal berbeda dan juga memiliki cara tersendiri di setiap negaranya. Amerika memiliki bahasa tanda yang digunakan oleh masyarakatnya yang menderita tunarungu yaitu American Sign Language (ASL atau Ameslan). Di Inggris, mengenal bahasa tanda yang digunakan oleh masyarakat Inggris atau disebut juga dengan British Sign Language (BSL). Kedua pengguna bahasa tersebut tidak saling memahami, karena kedua bahasa tersebut memiliki latar sejarah yang berbeda (Arifuddin, 2013). 
Indonesia juga memiliki Sistem Isyarat Bahasa Indonesia (SIBI). Sistem Isyarat Bahasa Indonesia (SIBI) yang dibakukan itu merupakan salah satu media yang membantu komunikasi sesama kaum tuna rungu dalam masyarakat yang lebih luas. Wujudnya adalah tatanan yang sistematis tentang seperangkat isyarat jari, tangan, dan berbagai gerak yang melabangkan kosa kata bahasa Indonesia. Dalam upaya pembakuan tersebut dipertimbangkan beberapa tolak ukur yang mencangkup segi kemudahan, keindahan dan ketetapan pengungkapan makna atau struktur kata, di samping beberapa segi yang.

\section{HASIL DAN PEMBAHASAN}

Pemerolehan bahasa bagi anak memiliki peranan penting untuk kemampuan berkomunikasi nantinya. Pemerolehan bahasa anak dapat dilihat dari bidang linguistik, yaitu fonologi, morfologi, dan sintaksis. Pemerolehan bahasa anak bersifat universal. Setiap tahapan pemerolehan bahasa anak itu sama. Tidak mungkin tahapan holofrastik mendahului tahapan cooing. Lain halnya dengan usia di setiap kemampuan bahasa masing-masing anak, sebagian anak usia tiga tahun sudah mampu mengucapkan huruf [r] dengan sempurna namun, ada sebagian anak yang telah berusia 5 tahun belum mampu mengucapkan huruf $[\mathrm{r}]$.

Rafi yang sudah menginjak usia empat tahun sudah mampu mengucapkan bunyi diftong dengan sempurna, antara lain bunyi [ia] dan [ie]. Contoh diftong terdapat dalam kata omiak, kambiang seperti yang terdapat dalam percakapan di bawah ini.

$\begin{array}{ll}\text { Rafi } & \text { : Bakpo ngubak a? } \\ & \text { 'Bagaimana cara membukanya?' } \\ \text { Penulis } & \text { :Nyak etek kubaan. } \\ & \text { 'Sini tante bukakan.' }\end{array}$

Mengenai gugus konsonan, Rafi sudah mampu mengucapkan gugus konsonan seperti yang terdapat dalam percakapan 1, 2, dan 3, yaitu [kp], [ng], [nt], dan [nj] terdapat dalam kata, bakpo, ngubak, ontan, dan lanjo .

Rafi sudah mulai menggunakan afiksasi di usia 4;5 tahun, namun Rafi lebih cendrung menggunakan kata dasar dibandingkan dengan kata dengan menggunakan afiks. Berikut contoh afiks yang digunakan oleh Rafi yang terbagi atas prefiks dan konfiks. Ayub (Ayub, 1993) menyatakan, ada sebelas prefiks dalam bahasa Minangkabau

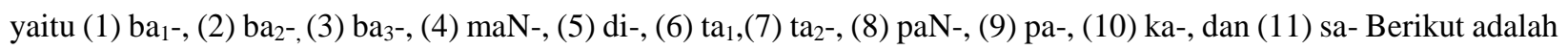
contoh prefiks dalam bahasa Minangkabau yang digunakan Rafi dalam percakapannya sehari-hari.

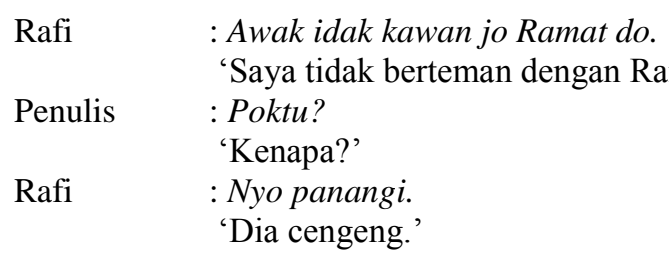

Saat berkomunikasi, Rafi belum banyak menggunakan konfiks, tetapi Rafi lebih banyak menggunakan gabungan afiks. Gabungan afiks yang digunakan oleh Rafi antara lain. 


$\begin{array}{ll}\text { disuak'an } & \text { 'disuapakan' } \\ \text { dikontuikan } & \text { 'dikentutkan' } \\ \text { disipak'an } & \text { 'ditendang' }\end{array}$

Pada usia Rafi yang sudah menginjak 4;5 tahun, Rafi termasuk anak yang sering menggunakan frasa dan klausa untuk berkomunikasi dengan orang di sekitarnya. Untuk menyatakan sebuah kalimat perintah, Rafi hanya menggunakan frasa verbal seperti.

$\begin{array}{ll}\text { nak poi } & \text { 'ingin pergi' } \\ \text { nak lanjo } & \text { 'ingin jajan' } \\ \text { nak minum } & \text { 'ingin minum' } \\ \text { nak makan } & \text { 'ingin makan' }\end{array}$

Dalam frasa verbal yang digunakan oleh Rafi di atas, semua anggota keluarga selain ibu Rafi akan paham maksud dari setiap frasa verba yang digunakan oleh Rafi untuk berkomunikasi. Saat Rafi menggunakan frasa verbal seperti nak poi, Rafi dan anggota keluarga lain sedang berada dalam konteks percakapan yang menyatakan tempat atau acara.

$\begin{array}{ll}\text { Nenek } & \text { : Lai ado jie ughang senam di dangau bu Ruzi Pi? } \\ & \text { 'Masih ada orang senam di rumah Bu Ruzi Pi?' } \\ \text { Rafi } & \text { : Lai potang. } \\ & \text { 'Masih kemaren.' } \\ \text { Nenek } & \text { : Gako nampak lo dek uwo e. } \\ & \text { 'Tadi nenek masih melihatnya.' } \\ \text { Rafi } & \text { : (Pergi ke pelukan neneknya) Nak poi! } \\ & \text { 'Ingin pergi!' }\end{array}$

Seperti yang telah dijelaskan di atas, Rafi dalam berkomunikasi sering menggunakan frasa dan klausa. Dalam frasa adjektival, Rafi bisa menggunakan pewatas kiri maupun pewatas kanan.

$\begin{array}{ll}\text { Penulis } & \text { : Lai mancibo pi mancoliak ulagh? } \\ & \text { 'Pernah Rafi melihat ular?' } \\ \text { Rafi } & \text { : Lai, ulagh bosagh. } \\ & \text { 'Pernah, ular besar.' } \\ \text { Penulis } & \text { : Di mano pi nampak? } \\ & \text { Di mana Rafi melihatnya?' } \\ \text { Rafi } & \text { 'Di lakang dangau.' } \\ & \text { 'Di belakang rumah.' } \\ \text { Penulis } & \text { : Tu lai pi bunua? } \\ & \text { 'Lalu ada Rafi bunuh?' } \\ \text { Rafi } & \text { : lai, mati kali } \text {. } \text { 'Ya, langsung mati.' }\end{array}$

Dalam frasa adjektiva ulagh bosagh, Rafi menggunakan pewatas kiri adjektiva, sedangkan dalam frasa adjektiva mati kali, Rafi menggunakan pewatas kanan adjektiva. Rafi juga menyertakan kata fatis dalam Minangkabau dengan menambahkan kata $a$ di akhir frasa adjektival.

Frasa nominal dalam usia Rafi, sudah banyak digunakan.

Penulis : : Di mano pi jatua potang?' 


\section{Jurnal Elektronik WACANA ETNIK - Vol 7 No 1 April 2018, (1 - 10) \\ p ISSN 2089-8746, e ISSN 2302-7142}

\section{Rafi :Daghi batang jambu. \\ 'Dari batang jambu.'}

Selain frasa nominal yang telah dikuasai oleh Rafi dalam percakapan di atas, Rafi juga telah menguasai frasa nominal lain seperti contoh di bawah ini.

$\begin{array}{ll}\text { Batang lansek } & \text { 'Pohon langsat' } \\ \text { Ungge awak } & \text { 'Burung saya' } \\ \text { Tablet awak } & \text { 'Tablet saya' } \\ \text { Batang jambu } & \text { 'Pohon jambu' }\end{array}$

Pada usianya, belum semua preposisi di kuasai oleh Rafi. Berikut beberapa preposisi bahasa Minangkabau yang digunakan di Halaban yang telah dikuasai Rafi.

$\begin{array}{ll}\text { di } & \text { 'di' } \\ \text { ka } & \text { 'ke' } \\ \text { daghi } & \text { 'dari' } \\ \text { untuak } & \text { 'untuk' } \\ \text { dek } & \text { 'oleh' } \\ \text { jak } & \text { 'seperti' }\end{array}$

Dalam penggunaan bahasa verbal, Rafi banyak menggunakan frasa atau klausa untuk berkomunikasi dengan orang lain selain ibunya. Walaupun demikian, Rafi telah mampu menggunakan kalimat baik tunggal maupun majemuk untuk berkomunikasi, namun tidak sesering Rafi menggunakan frasa dan klausa.

Pak Iman $\quad: P i$, buek'an an apak kopi di omiak ciek!

Rafi 'Pi, tolong buatkan ayah kopi sama ibu!' :Omiak mandi.

'Ibu mandi.'

Dalam percakapan di atas, terlihat Rafi menggunakan klausa Omiak mandi untuk menjawab kalimat perintah yang dituturkan oleh ayahnya. Di bawah ini terdapat contoh klausa yang sering digunakan saat berkomunikasi secara verbal oleh Rafi.

$\begin{array}{ll}\text { awak awi } & \text { 'saya haus' } \\ \text { omiak poi } & \text { 'ibu pergi' } \\ \text { lopen kambiang } & \text { 'melepaskan kambing' } \\ \text { nguwuang ayam } & \text { 'mengurung ayam' } \\ \text { jopuik rafa } & \text { 'menjemput rafa' } \\ \text { poi bawua } & \text { 'pergi ke bawah (kerumah rafa)' }\end{array}$

Seperti yang dikatakan di atas, bahwa Rafi sering menggunakan frasa untuk bertanya, atau untuk menggantikan kalimat perintah. Walaupun demikian, Rafi juga sudah menguasai penggunaan kalimat . Kalimat tersebut seperti kalimat deklaratif, kalimat tanya, kalimat interogatif, dan imperatif. Untuk kalimat majemuk, jarang digunakan oleh Rafi karena Rafi termasuk anak yang hemat bicara.

Nenek : : Poi kamano omiak Pi? 


\section{Jurnal Elektronik WACANA ETNIK - Vol 7 No 1 April 2018, (1 - 10) \\ p ISSN 2089-8746, e ISSN 2302-7142}
'Pergi kemana ibu Pi?'
Rafi : Omiak poi lopen kambiang.
' Ibu pergi melepaskan kambing.'

Dalam percakapan di atas, tampak Rafi telah mampu menggunakan kalimat dengan urutan $\mathrm{S}+\mathrm{P}+\mathrm{O}$. Perkembangan lain ialah Rafi mampu mengucapkan kalimat dengan urutan predikat+subjek, contoh :
Dimokan dek ayam
Tajatua awak
Olun baliak pak Iman lai

\author{
'Terjatuh saya' \\ 'Belum pulang pak Iman lagi.'
}
'Dimakan ayam'

Untuk berkomunikasi dengan seorang ibu tunarungu, Rafi menggunakan bahasa tanda. Bahasa tanda yang digunakan oleh Rafi dan ibunya menggunakan gerakan kepala dan gerakan tangan. Gerakan yang digunakan hanya berdasarkan persetujuan ibu Rafi dengan lingkungannya. Bahasa isyarat yang digunakan oleh Rafi tidak berdasarkan Sistem Isyarat Bahasa Indonesia (SIBI).

1. Mandi

Rafi kemudian memberi isyarat kepada ibunya menggunakan kedua tangannya. Bahasa tanda tersebut dilakukan dengan cara mengusap-usap kedua tangan di daerah perut dan dada. Gerakan yang dilakukan oleh Rafi kepada ibunya tampak menyerupai gerakan saat orang mengusapkan sabun ke tubuhnya. Isyarat tersebut menunjukkan bahwa ia ingin mandi. Saat penulis menanyakan maksud Rafi, dia menjawab dengan menggunakan bahasa verbal, "Nak mandi."

\section{Makan}

Dalam kesempatan lain, ibu Rafi bertanya dengan bahasa isyarat mengerucutkan tangan dan menggerakkan ke bawah ke atas yang mengarah pada mulut. Rafi kemudian mengangguk dan menunjukkan tangan ke arah rumah neneknya.

Isyarat yang digunakan ibu Rafi tersebut adalah meniru gerakan orang menyuapkan makanan ke mulut. Dalam komunikasi tersebut, maksud ibu Rafi adalah menanyakan “Apakah Rafi sudah makan?” Saat itu, Rafi menjawab dengan mengangguk dan menunjuk tangannya ke arah rumah neneknya berarti ia telah makan di rumah neneknya.

3. Air

Pada satu kesempatan penulis menjumpai Rafi yang ingin meminta air kepada ibunya. Bahasa tanda yang dilakukan oleh Rafi ialah dengan mengepalkan tangan dengan mengangkat ibu jarinya lalu menggerakkan ke arah gelas. Bahasa isyarat yang Rafi gunakan tersebut menyerupai gerakan menuangkan air.

Rafi memiliki cara yang berbeda untuk meminta air minum kepada ibunya. Rafi meminta minum kepada sang ibu dengan mengepal tangan dan menggerakkan ke arah mulut. Gerakan ini menyerupai gerakan orang minum dengan gelas.

4. Buang air besar 
Bahasa isyarat yang digunakan oleh Rafi saat akan buang air besar adalah menepuk-nepuk pantatnya beberapa kali. Ibu Rafi pun langsung merespons mengangguk lalu membuka celana Rafi dan mengambilkannya air. Sementara itu, Rafi menuju ke toilet untuk buang air besar.

5. Hujan

Karena keterbatasannya, ibu Rafi tidak bisa mendengar hujan turun. Satu ketika, penulis mengetahui Rafi memberitahu pada ibunya bahwa hujan mulai turun. Saat itu, Rafi mengetahui bahwa ibunya sedang menyuci pakaian. Rafi kemudian mengisyaratkan kepada ibunya bahwa hari telah hujan dengan cara membuka jari-jarinya seperti akan menggenggam sesuatu dan menggerakkannya ke atas dan ke bawah. Reaksi yang dilakukan oleh ibu Rafi yaitu segera mengangkat jemurannya yang berada di halaman rumah. Isyarat tersebut juga dilakukan oleh Rafi ketika ibunya menjemur pinang dan ketika mengikat kambing di luar kandang.

6. Nama benda

Rafi saat berkomunikasi secara verbal maupun nonverbal selalu merujuk pada benda-benda sekitar Rafi. Untuk membuka plastik makanan tersebut, Rafi tidak bisa melakukannya dengan tangan. Rafi menanyakan kepada ibunya letak gunting. Bahasa isyarat yang digunakan oleh Rafi untuk menanyakan gunting ialah dengan menggerakkan jari telunjuk dan jari tengah Rafi, dengan gerakan buka tutup. Gerakan tersebut menyerupai gerakan gunting.

Kebanyakan anak-anak menganggap semua benda bisa mereka jadikan mainan, seperti korek api. Padahal, bermain dengan korek api dapat membahayakan keselamatan anak-anak yang menggunakannya. Tak terkecuali Rafi. Karena keingintahuannya yang tinggi, Rafi adalah anak yang suka bermain dengan benda berbahaya seperti pisau, gunting dan korek api. Suatu saat penulis melihat Rafi ingin menggunakan korek api dengan membakar bungkus makanan ringan. Rafi meminta korek api kepada ibunya dengan cara mengepal dan menggerakkan ibu jari tersebut naik dan turun. Isyarat ini menyerupai tangan yang sedang menyalakan korek api.

Pada usia empat tahun ini, Rafi sudah mengenal uang sebagai alat tukar ekonomis, terutama untuk jajan. Rafi meminta uang kepada ibunya dalam bahasa isyarat dengan menggesekkan jari telunjuk dan jari tengah dengan ibu jari. Bahasa isyarat yang digunakan Rafi sama dengan gerakan isyarat tangan yang berarti uang.

Untuk menunjuk bola, Rafi menggunakan isyarat dengan mengayunkan salah satu kaki Rafi. Gerakan tersebut mirip dengan gerakan orang yang sedang menendang bola. Dengan isyarat itu, ibunya paham maksud Rafi yang menanyakan di mana ibunya menyimpan bola kesayangannya.

Komunikasi verbal dan nonverbal yang dilakukan Rafi kepada ibunya menunjukkan pola komunikasi yang biasa dilakukan oleh anak tuna rungu bukan bawaan. Menurut Ganur (Ganur, Bunga, \& Kiling, 2014), komunikasi anak tuna rungu bukan bawaan dilakukan dan ditegaskan melalui kontak mata, pengulangan, dan ekspresi wajah. Menariknya, Rafi melakukan hal itu atas dasar kebiasaan.

Hal tersebut sejalan dengan hasil penelitian Mursita (Mursita, 2015) tentang respons tuna rungu terhadap sistem bahasa isyarat seperti SIBI (Sistem Isyarat Bahasa Indonesia) dan BISINDO (Bahasa Isyarat Indonesia). Dalam 


\section{Jurnal Elektronik WACANA ETNIK - Vol 7 No 1 April 2018, (1 - 10)}

p ISSN 2089-8746, e ISSN 2302-7142

penelitiannya itu, Mursita menemukan penyandang tuna rungu kurang mendukung penggunaan SIBI yang lebih sistemik jika dibanding BISINDO yang alami. Komunikasi antara Rafi dengan ibunya menunjukkan proses komunikasi yang alami dan merupakan bentuk komunikasi total (Rofiandaru, 2013). Komunikasi total adalah suatu pendekatan dalam pendidikan bagi kaum tunarungu yang menganjurkan penggunaan berbagai bentuk media komunikasi yaitu oral, aural dan manual untuk meningkatkan keterampilan berbahasa.

Di sisi lain, kemampuan Rafi untuk berkomunikasi secara verbal dan nonverbal secara tidak langsung menunjukkan tingkat kecerdasan Rafi. Indah (Indah, 2011) menegaskan perkembangan bahasa sering menjadi tolok ukur tingkat intelegensi anak meskipun pada hakikatnya perkembangan seorang anak merupakan suatu kesatuan yang utuh dan saling melengkapi. Artinya seorang anak tidak dapat dikatakan cerdas jika dia hanya bisa memecahkan masalah visuo-motor dan fasih berbahasa tanpa diimbangi kemampuan bersosialisasi. Ketika seorang anak sedang memperoleh bahasa B1-nya, terjadi dua proses, yaitu proses kompetensi dan proses performasi. Kedua proses ini merupakan dua proses yang berlainan. Kompetensi adalah proses penguasaan tata bahasa yang berlangsung secara tidak disadari. Proses kompetensi ini menjadi syarat untuk terjadinya proses performasi yang menyangkut proses pemahaman dan proses memproduksi ujaran. Proses pemahaman melibatkan kemampuan memersepsi kalimat yang didengar. Sedangkan proses memproduksi ujaran menjadi kemampuan linguistik selanjutnya.

Kondisi keluarga Rafi dan lingkungan tempat tinggalnya menunjukkan toleransi yang tinggi kepada penyandang keterbatasan pendengaran. Bentuk toleransi tersebut dicerminkan dengan hubungan harmonis antara anak yang normal dengan ibu yang tuna rungu. Lingkungan masyarakat juga tampak mendukung bentuk toleransi tersebut. Hal ini menunjukkan pula penyesuaian sosial yang cukup maksimal. Solikhatun (Solikhatun, 2013) menegaskan Penyesuaian sosial bagi penyandang tunarungu adalah semata-mata untuk menyesuaikan dirinya pada lingkungan sekitar agar dapat berinteraksi dengan baik pada lingkungan sosialnya. Apabila penyandang tunarungu tidak dapat melakukan penyesuaian sosial dengan baik maka akan mengalami hambatan atau konflik dalam setiap langkahnya dalam berhubungan dengan orang lain, kurang mampu menyesuaikan diri dan merasa dirinya tidak berharga.

\section{PENUTUP}

Penggunaan bahasa tanda oleh Rafi tidak berdasarkan Sistem Isyarat Bahasa Indonesia (SIBI), melainkan hanya kesepakatan antara Ibu Rafi dengan lingkungannya termasuk dengan Rafi. Bahasa tanda yang digunakan Rafi untuk berkomunikasi dengan ibunya ialah mandi, makan, meminta air, jajan, ingin buang air, merasa sakit, memberi tahu hari hujan, mengisyaratkan agar menunggu, membeli pistol mainan, minta tolong membuatkan kopi, gunting, korek api, HP, uang, bola, ayah, nenek, kakek, ular ayam, dan kambing. Bahasa tanda yang dilakukan oleh Rafi ialah dengan menunjuk langsung ke pada objek yang ia maksud.

Komunikasi dwisistem ini tidak berpengaruh terhadap perkembangan bahasa verbal Rafi. Rafi masih bisa berkomunikasi secara normal tanpa gangguan bicara. Rafi tahu kapan ia harus menggunakan bahasa verbal dan kapan ia harus menggunakan bahasa tanda. 


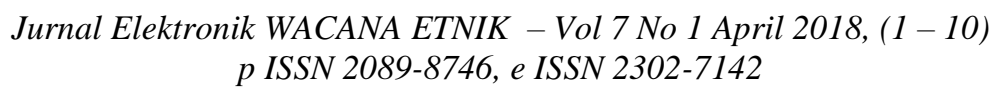

\section{DAFTAR PUSTAKA}

Arifuddin. (2013). Neuropsikolinguistik. Jakarta: PT Raja Grafindo Persada.

Ayub, A. (1993). Tata Bahasa Minangkabau. Jakarta: Pusat pembinaan dan Pengembangan Bahasa Departemen Pendidikan dan Kebudayaan.

Chaer, A. (2003a). Linguistik Umum. Jakarta: Rineka Cipta.

Chaer, A. (2003b). Psikolinguistik Kajian Teoritik. Jakarta: PT Rineka Cipta.

Dardjowidjojo, S. (2012). Psikolinguistik Pengantar Pemahaman Bahasa Manusia. Jakarta: Yayasan Pustaka Obor Indonesia.

Djajasudarma, F. (1993). Sematik 1 Pengantar ke Arah Ilmu Makna. Bandung: Eresco.

Ganur, M. H., Bunga, B. N., \& Kiling, I. Y. (2014). Pola komunikasi anak usia dini tunarungu bukan bawaan, (January). Retrieved from https://www.researchgate.net/publication/324007126

Indah, R. N. (2011). PROSES PEMEROLEHAN BAHASA: DARI KEMAMPUAN HINGGA KEKURANGMAMPUAN BERBAHASA. LiNGUA: Jurnal Ilmu Bahasa Dan Sastra, 3(1). https://doi.org/10.18860/ling.v3i1.570

Moores, D. F. (2001). Educating the Deaf: Psyclogoy, Principles, and Practices. (I. D. Aprilia, Ed.). Boston: Houghton Mifflin Company.

Mursita, R. A. (2015). RESPON TUNARUNGU TERHADAP PENGGUNAAN SISTEM BAHASA ISYARAT INDONESA (SIBI) DAN BAHASA ISYARAT INDONESIA (BISINDO) DALAM KOMUNIKASI. INKLUSI, 2(2), 221. https://doi.org/10.14421/ijds.2202

Rofiandaru, M. (2013). SISTEM PEMBELAJARAN BAHASA ISYARAT (SIBI) MENGGUNAKAN METODE KOMUNIKASI TOTAL UNTUK PENYANDANG TUNARUNGU DI SLBN SEMARANG. Universitas Dian Nuswantoro Semarang.

Solikhatun, Y. U. (2013). PENYESUAIAN SOSIAL PADA PENYANDANG TUNARUNGU DI SLB NEGERI SEMARANG. Educational Psychology Journal, 2(1). Retrieved from https://journal.unnes.ac.id/sju/index.php/epj/article/view/2588

Tarigan, H. G. (1988). Pengajaran Kedwibahasaan. Bandung: Angkasa. 